\title{
NATURALEZA VERSUS INDIVIDUO EN LA OBRA POÉTICA DE SYLVIA PLATH
}

\author{
Ana M. Martín Castillejos. Escuela Técnica Superior de Arquitectura de \\ Madrid
}

\begin{abstract}
Sylvia Plath vivió gran parte de su vida en lugares donde la presencia de la naturaleza era notable y cuyos escenarios plasmó en su obra. El presente artículo examina la forma en que el individuo se relaciona con el medio natural en su obra poética y describe cómo, aunque los sentimientos que surgen como resultado de tal interacción son variados y evolucionan, hay ciertos elementos que permanecen constantes a lo largo de todo su cuerpo poético, tales como el sentimiento de vulnerabilidad, hostilidad y agresión que el mundo natural provoca a menudo en los protagonistas de sus poemas. No hay posibilidad de fusión, de identificación, tal como Plath anhela, ya que la bondad y belleza primigenias del mundo natural no están al alcance del ser humano. La respuesta que la naturaleza da al individuo de forma insistente es la de la alienación y separación irreconciliables.
\end{abstract}

La presencia del mundo natural en toda la obra poética de Sylvia Plath resulta un hecho evidente. Su genuino interés por el ámbito natural está relacionado con su deseo de conocer el medio que le rodea, con su programa de "reaprender a mirar":

... A esta finalidad y al deseo de descubrir la relación intrínseca y soterrada de las cosas responde también su afán de formación casi enciclopédica que la hace explorar áreas de conocimiento distintas ... Sus ejercicios de observación y contemplación le hacen profundizar en el misterio de la naturaleza y motivan el estudio de la vida oculta de animales y plantas. Su dominio científico de la biología tan sorprendentemente amplio le confirió la concreción del lenguaje y la precisión necesaria para una nueva expresión poética que le permitirán el acercamiento a posiciones poundianas ... (Pâtea, 1989: 120)

La misma Plath hace alusión a su interés por aprender sobre lo que le rodea en cartas y comentarios escritos en sus diarios. Por ejemplo, en estos últimos escribe: “... I'm plowing through Penguin books on Aztecs, the personality of animals, man and the vertebrates. So much to read ..." (2000: 399), o también, “... Looked up spiders and crabs and owls in the 
sticky deserted gloom of the college library" (2000: 399). De igual forma, en una de las más de 600 cartas enviadas a su madre, Plath admite,

... I am becoming more and more desirous of being an amateur naturalist. Do you remember if we have any little books on recognizing wild flowers, birds, or animals in Northern America? I am reading some Penguin books about "Man and the Vertebrates" and "The Personality of Animals" and also the delightful book The Sea Around Us, by Rachel Carson ... I am going back to the ocean as my poetic heritage ... (1992: 345) (5 de julio de 1958)

El resultado de este interés y curiosidad de Plath es un cuerpo poético en el que el número de poemas cuyo tema es el mundo natural es claramente significativo; son poemas que salpican toda su carrera literaria, desde su "Juvenalia" ("April Aubade", "Aquatic Nocturne", "Metamorphoses of the Moon", etc.) a sus últimos versos escritos, publicados principalmente en Ariel ("Poppies in October", "Ariel”, "Sheep in Fog", etc).

Pero aparte de su curiosidad natural, el interés de la escritora por el ámbito de la naturaleza se vió, sin duda, incentivado por el hecho de que Ted Hughes, el escritor británico con quien estuvo casada durante más de seis años, era un hombre estrechamente vinculado a la tierra que plasmaría en poderosos poemas sus impresiones del mundo natural $^{1}$. Así pues, no es de extrañar que la primera descripción que Plath hace a su madre del que sería su marido sea la de un personaje surgido de algún lugar en plena naturaleza, muy lejos de la sofisticación de las grandes ciudades: "Ted is incredible, mother ... wears always the same black sweater and corduroy jacket with pockets full of poems, fresh trout and horoscopes ..." (Letters Home, 1992: 243-44).

Nacido en Calder Valley, en los "Yorkshire Pennines", hijo de carpintero y el menor de tres hermanos, Hughes pertenecía por entero a los páramos de Yorskshire, una tierra inhóspita pero inolvidable, de las que imprimen carácter. Siendo niño, solía ir con su hermano mayor a cazar lechuzas, ratas, conejos, urracas, comadrejas y otros animales típicos de la zona, según él mismo explica ${ }^{2}$. Respecto al condado de Yorkshire y sus habitantes, Louis Simpson recoge así el testimonio del escritor:

He has spoken of "the peculiar and desolate spirit that cries in telegraph wires on moor roads, in the dry and so similar voices of grouse and sheep, and the moist voices of curlews." Everything in West Yorkshire is "slightly unpleasant." The people seem only half-born from the earth, and the graves are too near the surface. "A disaster seems to hang around in the air there for a long time. I can never escape the impression that the whole region is in mourning for the first world war." And yet, inspite of this "the moorland is exultant, and," Hughes says, "this is what I remember of it.” (1978: 111)

\footnotetext{
${ }^{1}$ En realidad, los poemas donde Hughes reflexiona sobre la relación del hombre con la naturaleza salpican toda su trayectoria poética. Un buen ejemplo es su temprano "Pennines in April", perteneciente a Lupercal (1960), pero también lo son otros poemas como "Pibroch", de Wodwo (1967), "Crow's Elephant Totem Song", de Crow (1972), "Telegraph Wires", perteneciente a su colección Wolfwatching (1989), etc.

${ }^{2}$ Ted Hughes, "Capturing Animals" en Poetry Is (1970: 10), citado por Louis Simpson en A Revolution in Taste (1978: 111).
}

Odisea, $\mathrm{n}^{\circ} 2,2002$ 
Asimismo, Hughes creía que las verdades que subyacen en nuestro subconsciente son las mismas que las que rigen el mundo natural, y estaba convencido de la existencia de una conexión mágica entre el yo auténtico del hombre y el alma de la naturaleza, de forma que lo que imaginamos sobre la naturaleza se hace realidad; de la misma manera, cuando entramos en buena sintonía con objetos o criaturas del mundo natural, éstos entran en nuestra mente y adquieren cierto control sobre ella (Picot, 1997: 166).

Hughes, tal como nos cuenta Edward Picot, expone sus propias teorías sobre la expulsión del hombre del Edén en su artículo "Myth and Education" y en un poema de su libro Crow (1970) titulado "Crow's Elephant Totem Song" en los que explica cómo el ser humano ha caído en desgracia como consecuencia de su pérdida de contacto con su propio yo y no tanto como consecuencia de su pérdida de contacto con el mundo natural. Hughes cree que volver a ponernos en contacto con nuestro inconsciente supone a la vez ponernos de nuevo en contacto con el mundo natural, y viceversa, ya que las verdades últimas subyacentes en ambos son las mismas.

El escritor afirma también que si lográsemos captar una imagen de nuestro yo auténtico, interior, en un espejo, esta imagen sería la de una especie de reptil descomponiéndose en el infierno (Hughes, 1994: 137). Esta es la forma en que Hughes asocia el interior del ser humano con el mundo natural, lo que a veces le ha llevado a utilizar imagenes de animales antropomórficos y pájaros para representar estados de la consciencia humana. Otro aspecto importante a señalar respecto a la concepción del cosmos de Hughes es su creencia en la teoría de la fuerza vital según la cual todo el cosmos está regido por una fuerza que se enfrenta continuamente con la muerte y resulta derrotada, aunque inmediatamente después de la derrota este principio vital reaparece adoptando una nueva forma, un aspecto distinto, en un lugar diferente. Hughes celebra en sus escritos la existencia de esta fuerza vital a la vez que se lamenta del estado en el que se encuentra la civilización occidental, una civilización que la ha enterrado e incluso ha negado su existencia (Picot, 1997: 159).

Esta negatividad de base en la concepción del yo auténtico del hombre y la idea de la rebelión de la naturaleza o de la posibilidad de una reacción imprevista como respuesta al comportamiento excesivo del ser humano, vamos a verlas reflejadas también en la poesía de Plath más adelante.

En realidad, tanto en la obra de Hughes como en la de Plath el sentimiento de alienación del hombre respecto de la naturaleza es un hecho más que evidente, sin embargo, posiblemente ambos se vuelvan hacia la naturaleza porque, como explica Picot, el hombre "envies the apparent unconscious contentment of the non-human world; and often he turns towards that world with a sense of release, simply because it is different from his own creations, and therefore offers him a moment of escape from his own problems" (1997: 293). Efectivamente, el ser humano tiende a pensar que en el mundo natural no es suceptible de sufrimiento y es ahí, por tanto, donde espera encontrar alivio a las penas que le afligen.

No obstante, el abuso sistemático que el hombre ha ejercido sobre la naturaleza ha hecho que, tal como explican T.W. Adorno y M. Horkheimer, "Men pay for the increase of their power with alienation from that over which they exercise their power. Enlightenment behaves toward things as a dictator toward men. He knows them in so far as he can manipulate them" (2000: 77). Aunque tanto Plath como Hughes son conscientes de tal alienación, en el segundo se atisba cierta esperanza ya que el escritor cree en la capacidad inherente al ser humano para "curar" la alienación del hombre respecto a sí mismo y a la naturaleza (Gifford, 2000: 222), teoría que queda de manifiesto en poemas como "Cave Birds". 
En cuanto a Plath, la influencia que Hughes ejerce en su escritura se va a reflejar predominantemente en dos aspectos: en la aparición de personajes imaginarios en su obra y en la preponderancia que los paisajes naturales adquieren sobre los urbanos (Pâtea, 1989: 138-39). Respecto a la forma en que la escritora presenta la naturaleza en su obra ésta va cambiando con el tiempo y hay críticos que afirman que los poemas que escribe en su primera época se parecen tan poco a los de su último período, que se dirían escritos por distintas personas. Según Jon Rosenblatt, uno de los críticos que mantienen esta teoría, la primera obra de Plath ni tan siquiera se asemeja a lo que vamos a ver después: "Sylvia Plath's early work differs so greatly from her late poetry both in style and in substance that they would appear to have been written by two different poets ... her apprentice poems (1950-56) neither hint at these concerns nor suggest the power and psychological dynamics of Ariel and Winter Trees" (1979: 47). Para este crítico, por tanto, "Only the general mood of depression and fear in this body of work anticipates the character of the late poetry" (1979: 47).

No obstante, cabe afirmar que, además de en el tono, hay también una clara continuidad en la utilización de temas e imágenes que resultan recurrentes a lo largo de toda su vida literaria. Así, por ejemplo, el tema del mundo natural está presente desde el principio, de forma que, como señala Edward Lucie-Smith, cabría reconocer cierta continuidad en la evolución de Plath como escritora:

The more closely one studies her work, the less convincing becomes the theory of a dramatic 'break', which is, I think, an essential part of Alvarez's view of it. There is no question that Sylvia Plath developed considerably as a poet. She was the very opposite of an idle writer -she was extremely ambitious, and she took a close interest in her craft. The basic themes, the basic materials of her poetry (some of them almost too frightening for anyone to confront) were there from the very beginning- it was simply that she learned to deal with them more truthfully, more incisively and more originally ... (1970: 98)

La evolución que se observa en la poesía de Plath es, por tanto, formal y estilística principalmente, no de concepto, pues las preocupaciones y temas básicos en su obra están presentes desde el principio. En sus primeros poemas sobre la naturaleza, Plath describe lo que ve, poética pero realísticamente. Tal es el caso de poemas escritos en 1956 como "Conversation Among the Ruins", "Southern Sunrise", "Prospect", "Faun", "Alicante Lullaby" y "Dream with Clam-Diggers" entre otros. Veamos unos ejemplos de este tipo de descripción naturalista:

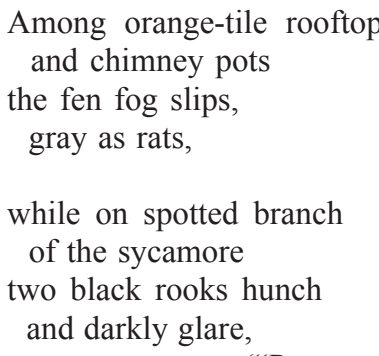

("Prospect", The Collected Poems, 1981: 28, versos 1-8) 
In Alicante they bowl the barrels

Bumblingly over the nubs of the cobbles

Past the yellow-paella eateries,

Below the ramshackle back-alley balconies,

While the cocks and hens

In the roofgardens

Scuttle repose with crowns and cackles.

(“Alicante Lullaby", The Collected Poems, 1981: 43, versos 1-7)

Barefoot, she stood, in shock of that returning,

Beside a neighbor's house

With shingles burnished as glass,

Blinds lowered on that hot morning.

("Dream with Clam-Diggers", The Collected Poems, 1981: 43, versos 1-7)

En todos los poemas de su primera época y aun en algunos de los publicados en The Colossus la predominancia de la forma sobre el fondo va a ser notoria. El rigor formal existente en los versos junto al hecho de que muchos tienen un narrador en tercera persona, hace que el lector no se involucre demasiado en lo que se narra y en que se atisbe todavía cierta capacidad de control del personaje principal sobre su medio, incluso en los casos en que éste resulta claramente hostil.

Más adelante, en su época transicional, el paisaje aparece más bien como una construcción mental de la escritora, quien plasma su mundo interior en la realidad física que le rodea. Tal es el caso de poemas pertenecientes a 1961 como "Tulips", "Finisterre", "Wuthering Heights", "Blackberrying" "Stars over the Dordogne" y otros, en los que la fusión entre sujeto y naturaleza es evidente. Estos poemas, en su mayoría escritos en primera persona, propician la implicación del lector y, a la vez, al estar menos constreñidos por reglas formales, nos muestran a un protagonista que a menudo se debate por lograr cierto control sobre su medio y circunstancias. Un ejemplo de esta lucha estéril por sobreponerse al medio y dominarlo lo tenemos en "Tulips", donde unas flores aparentemente inocentes amenazan la identidad de la escritora, le hacen recordar lo frágil que es, la hieren con su color, color de sangre y vida, y le hacen verse como "flat, ridiculous, a cut-paper shadow", casi inexistente.

The tulips are too red in the first place, they hurt me.

Even through the gift paper I could hear them breathe

Lightly, through their white swaddlings, like an awful baby.

Their redness talks to my wound, it corresponds.

They are subtle: they seem to float, though they weigh me down, Upsetting me with their sudden tongues and their color,

A dozen red lead sinkers round my neck.

Nobody watched me before, now I am watched.

The tulips turn to me, and the window behind me

Where once a day the light slowly widens and slowly thins,

And I see myself, flat, ridiculous, a cut-paper shadow

Between the eye of the sun and the eyes of the tulips, 
And I have no face, I have wanted to efface myself.

The vivid tulips eat my oxygen.

(“Tulips" en The Collected Poems, 1981: 161, versos 36-49)

Ahora se empieza a observar lo que luego será aún más evidente: que en el universo descrito por Plath la naturaleza obedece también a un orden moral y que es suceptible de maldad, de hacer sufrir a aquel que, en definitiva, ha abusado de ella y le ha dado la espalda.

Hay, no obstante, un paso más en la evolución de la obra poética de Plath y es el de la fusión de la realidad mental de la escritora con la realidad exterior, tangible, de forma que no es fácil distinguir la primera de la segunda. En esta categoría tendríamos que incluir poemas de su última época publicados en su mayoría en Winter Trees y Ariel, tales como "Ariel”, "Poppies in October", "Getting There", "Years", "Winter Trees", "Sheep in Fog" y, en general, aquellos poemas sobre la naturaleza escritos principalmente en la segunda mitad de 1962 y en 1963 . Veamos también algunos ejemplos:

White

Godiva, I unpeel-

Dead hands, dead stringencies.

And now I

Foam to wheat, a glitter of seas.

The child's cry

Melts in the wall.

(“Ariel” en The Collected Poems, 1981: 239, versos 19-25)

All morning the

Morning has been blackening,

A flower left out.

My bones hold a stillness, the far

Fields melt my heart.

("Sheep in Fog" en The Collected Poems, 1981: 262, versos 8-12)

En cuanto a la técnica que Plath utiliza en estos últimos poemas, ésta ha cambiado radicalmente respecto a los primeros. La mayoría de los versos son de rima libre y no están encorsetados para conseguir efectos formales. Ejemplos de esto son poemas como "Lady Lazarus", "Cut", "Elm", "Daddy, "Medusa", y otros donde la libertad formal es evidente y donde el ritmo se acelera hasta adquirir, a veces, un carácter frenético y un tanto histérico. La sensación de velocidad que se obtiene cuando se leen algunos de los poemas es evidente y las imágenes que se derivan de su lectura se parecen a los cuadros de los futuristas quienes, acaudillados por Marinetti, intentaban transmitir el movimiento y la velocidad en sus cuadros utilizando brochazos enérgicos, rotundos, y descartando el naturalismo reinante anterior al surgimiento de los "ismos" con la llegada del arte abstracto.

En estos poemas de Plath las estrofas se acortan respecto a los versos de su primera época y muchas de ellas no tienen más de dos o tres versos. A su vez, en ocasiones, cada verso contiene sólo unas cuantas palabras a modo de pinceladas rápidas y enérgicas. Estos son unos ejemplos: 
Peel off the napkin

O my enemy.

Do I terrify?-

("Lady Lazarus", The Complete Poems, 1981: 244, versos 10-12)

Touching and melting.

Nowhere

(“The Night Dances", The Complete Poems, 1981: 250, versos 27-28)

The size of a fly,

The doom mark

Crawls down the wall.

(“Contusion", The Complete Poems, 1981: 271, versos 7-9)

La evolución estilística de Plath es, en realidad, la que se observa en otras artes como pintura o escultura: desde un naturalismo clásico donde la descripción prima sobre todo lo demás hacia el expresionismo y la abstracción donde cada palabra se asemeja a un brochazo o a un golpe de martillo (Applewhite, 1985: 214). Así, vemos claramente cómo el estilo naturalista de los versos escritos en su primera etapa da lugar a un estilo casi abstracto. En realidad, la evolución pictórica o escultórica del aprendiz que poco a poco forja un estilo propio y es capaz de expresarse en términos más económicos es enteramente trasladable a la evolución que vemos en la escritura de Plath. No es pura coincidencia el hecho de que la escritora escogiera a pintores como Giorgio de Chirico y Paul Klee para buscar inspiración poética, o a escultores como Leonard Baskin, artistas que se habían planteado abiertamente la evolución de su obra desde el naturalismo a la pintura metafísica y el futurismo (Chirico) o al expresionismo, primer surrealismo y posterior abstracción, que constituyen las distintas etapas pictóricas del inquieto y magistral Klee.

La carácterística común que encontramos en los últimos versos de Plath, en los que la plasmación de la mente aparece como dominante, es la misma que J. Douglas Portuous describe para otros escritores tales como Malcolm Lowry, cuya vida atormentada aparece reflejada en sus paisajes:

Like so many travellers, Lowry used his journeys to map the terra incognita of his own mind. His tormented and deeply divided mind, forever oscillating between elation and despair, redemption and salvation, vested its own distinctive qualities in the landscapes he encountered. These landscapes thus became not merely a backdrop for his life but part of his personality, expressed as the personalities of his characters ... The landscapes of Lowry's novels, then, are not merely real or even imagined landscapes, products of his mind; they have, in a sense, become his mind. (1990: 104) (énfasis mío)

Estas palabras son perfectamente aplicables al último poema de Plath que hemos citado, "Ariel", donde la separación entre lo que pasa por la mente de Plath y lo que ocurre de verdad alrededor de ella es ciertamente imposible:

God's lioness,

How one we grow,

Pivot of heels and knees!-The furrow

Odisea, $\mathrm{n}^{\mathrm{o}} 2,2002$ 
Splits and passes, sister to

The brown arc

Of the neck I cannot catch

(“Ariel”, The Complete Poems, 1981: 239, versos 4-9)

Esta misma idea aparece también en Portuous cuando se refiere a la relación que se establece entre el paisaje y la mente del individuo en la obra de algunos escritores. Dice así:

The complex relationship between landscape and the human mind varies from utilitarian data-gathering, at one extreme, to identification at the other. Meinig's ... ten 'views' of landscape are not exhaustive, for he fails to consider the notion discussed in this chapter, that mind and landscape interpenetrate and become almost interchangeable, that landscape imprints on mind, that landscape, as it were, becomes self. Pocock ... comes close to this position in his assertion that 'place may be considered as people and people as place'. (1990: 104)

Aunque podemos hablar de una continuidad de temas en su obra entre los que la del mundo natural resulta patente, la interrelación que Plath describe entre ser humano y paisaje no es siempre, ni mucho menos, la misma, sino que es variada y se va alterando con el tiempo. Así, nos encontramos con poemas en los que el medio natural supone una clara amenaza para el hombre y donde la sensación de hostilidad queda patente (así en "Tulips", "Frog Autumn", "Blue Moles" y "Point Shirley", por ejemplo); otros en los que el ser humano se presenta como un intruso en el mundo natural ("Two Campers in Cloud Country", "Finisterre"); también hay poemas en los que se resalta la absoluta vulnerabilidad del ser y su imposibilidad para ejercer ningún control sobre el medio ("Hardcastle Crags", "Wuthering Heights"); además, vemos una actitud de indiferencia de la naturaleza hacia el individuo que ocasiona en éste un sentimiento de ausencia al comparar su propia realidad con aquella que le rodea ("Winter Trees"); finalmente, entre todo este tipo de interrelaciones, observamos también la que Plath convierte en característica propia y más definitoria al final de su obra: el sentimiento de identificación y fusión entre paisaje y sujeto ("Elm", "Edge", etc), al que ya hemos hecho referencia y del que volveremos a hablar.

\section{HOSTILIDAD}

Respecto a la primera sensación citada, tenemos que hacer notar que Plath misma afirma en su relato "Ocean 1212-W" que tal sentimiento de hostilidad o, al menos, de "extrañamiento" respecto al mundo circundante aparece siendo niña: "As from a star I saw, coldly and soberly, the separateness of everything ... My beautiful fusion with the things of this world was over" (Johnny Panic and the Bible of Dreams, 1977: 126). También, en este sentido, podemos hacer alusión a poemas como "Tulips", en el que una primera sensación de extrañamiento se va convirtiendo, progresivamente, en otra de clara y abierta hostilidad: así, unas simples flores rojas enviadas al hospital para alegrar la habitación de la paciente destruyen su paz y la llenan de inquietud y desasosiego. El rojo intenso de las flores le recuerda sus heridas (posiblemente las de su cuerpo tanto como las de su alma): "it talks to my wound", afirma la paciente, y las flores son descritas acto seguido como poseedoras de 
vida propia: respiran, tienen lenguas y sus pétalos se enrollan alrededor de su cuello. A medida que las flores parecen agrandarse y cobrar fuerza la paciente parece empequeñecer $\mathrm{y}$ debilitarse, de forma que hacia el final del poema llegan a ser descritas como "dangerous animals" que deberían estar enjaulados ("the tulips should be behind bars") (Ariel, 1965: 1012). La paciente odia las flores porque le recuerdan la intensidad de la vida que transcurre fuera del hospital, mientras que a ella le gustaría sumergirse en la pasiva extinción a que parecen invitar las blancas paredes de la habitación. Como bien señala Marjorie Perloff, al final del poema hay referencias a la fusión entre los tulipanes rojos y la paciente, que devienen una sola cosa:

The whole poem is organized around two central images: white and red - the white of human extinction and the red of living matter, of non-human vitality, or again, the white of angst and the red of animism. Like a "great African cat" opening its mouth, the red flower finally absorbs the world of selfhood into its strange domain: flower petal and human blood become one ... (1984: 119)

En otro poema, "Mussel Hunter at Rock Harbour" la hostilidad del paisaje no es tan patente pero sí el extrañamiento respecto del sujeto, sensación que se agrava en las tres últimas estrofas del poema, en las que hay una alusión directa a la muerte. Donde el tema de la hostilidad del medio natural sobre los seres vivos es también muy obvio es en "Frog Autumn" y en "Blue Moles". En el primero de ellos la naturaleza "permite", impasible, que las ranas se mueran de hambre,

\section{... Clearly}

The genius of plenitude

Houses himself elsewhere. Our folk thin

Lamentably.

(The Colossus and Other Poems, 1962: 68, versos 9-12)

Como Ingrid Melander señala, no es casual que "lamentably" aparezca como única palabra en el último verso del poema: "The position of this word, with the heavy stress laid on it, makes it stand out as particularly relevant to the thematic development of the poem. Our attention is thus drawn to a word that expresses regret and grief, and we are made deeply conscious of the poet's compassionate attitude to the starving frogs" (1972: 54). Efectivamente, el último verso del poema expresa lo que la escritora siente al respecto: Plath se pone del lado de las "victimizadas" ranas ante lo que considera una actitud cruel de las fuerzas naturales.

En el segundo poema mencionado, "Blue Moles", Plath carga de nuevo las tintas sobre lo hostil que la naturaleza ha sido para los indefensos topos cuando se refiere a ella como "bad nature" (The Colossus and Other Poems, 1962: 49, verso 9). La escritora hace un juicio moral explícito sobre la naturaleza en este poema al describirla como una fuerza básicamente despiadada y destructiva.

Esta insistencia en otorgar al mundo natural cualidades humanas y morales es algo que Plath heredó en parte de los escritores románticos, de quienes presenta evidente influencias literarias, sin embargo, mientras que para autores como Wordsworth la naturaleza es fuente de placer (Roszak, 2000: 110) para Plath lo es de dolor. De esta manera, los siguientes versos de Wordsworth, impregnados de calma y serenidad, contrastan con los que hemos visto y veremos a continuación en Plath: 
I held unconscious intercourse with beauty

Old as creation, drinking in a pure

Organic pleasure from the silver wreaths

Of curling mist, or from the level plain

Of waters colored by impending clouds . . .

To every natural form, rock, fruit, or flower,

Even the loose stones that cover the highway,

I gave a moral life: I saw them feel,

Or linked them to some feeling: the great mass

Lay bedded in a quickening soul, and all

That I beheld respired with inward meaning.

(cit. en Roszak, 2000:110)

Otro poema que versa sobre la hostilidad de las fuerzas naturales en Plath, en esta ocasión del mar, y que, por tanto, contrasta claramente con la imagen ofrecida por el poeta inglés es "Point Shirley", en el que se enfatiza el hecho de que el poder destructor de la naturaleza es superior al poder creador del hombre y, así, obtenemos la imagen de la abuela de Plath luchando arduamente contra la bravura del mar en unos versos:

She is dead,

Whose laundry snapped and froze here, who

Kept house against

What the sluttish, rutted sea could do.

(The Colossus and Other Poems, 1962: 24, versos 9-12)

Sin embargo, la mención de la muerte de la anciana al final del poema nos deja de nuevo con la sensación de derrota final que mencionábamos. Como dice A.E. Dyson, “... nature outlasts man, and wins again in the end" (1970: 205).

Igualmente en "Departure" el mar aparece como fuerza violenta. Basado en los recuerdos de Plath de su luna de miel en Benidorm, España, junto a su esposo, el elemento marino es descrito como "brutal endlessly", de forma que Plath pone énfasis en la fuerza persistentemente destructora del mar.

Otros poemas sobre el mismo tema son "Hardcastle Crags" y "Wuthering Heights", ambos enmarcados en el mismo paisaje hostil de los páramos de Yorkshire. El segundo sobre todo muestra de forma rotunda la hostilidad de los inhóspitos páramos ingleses: "There is no life higher than the grasstops / Or the hearts of sheep" (Crossing the Water 1971: 1, versos 10-11). Pero la hostilidad no pertenece sólo a los páramos, también en desiertos como el de Mojave es evidente. Así, "Sleep in the Mojave Desert" es un poema basado en un viaje en coche de Plath y su marido por los Estados Unidos durante el verano de 1959, donde la escritora explica cómo el calor se ceba sobre todo ser vivo, haciéndole padecer. Allí, hasta el aire es peligroso:

Out here there are no hearthstones,

Hot grains, simply. It is dry, dry.

And the air dangerous. 
The sun puts its cinder out. Where we lie

The heat-cracked crickets congregate

In their black armorplate and cry.

(Crossing the Water, 1971: 29, versos 1-3, 21-23)

Es éste un paisaje hostil que no invita a la vida y donde las criaturas sobreviven sufriendo el medio en el que están inmersas.

\section{INTRUSISMO E INDIFERENCIA}

Íntimamente ligado a la sensación de hostilidad está el tema del intrusismo, la naturaleza es hostil al hombre porque éste le es ajeno y, además, ha abusado de su poder sobre ella. De esta manera, en algunos de los poemas ya citados como "Wuthering Heights" los temas de la hostilidad, el intrusismo y la indiferencia de la naturaleza ante sus criaturas se entrecruzan: Plath no es más que un testigo pasivo de un mundo turbulento en el que no tiene ninguna capacidad de actuación. La escritora enfatiza en el poema la indiferencia del medio ante el ser humano: "Of people the air only / Remembers a few odd syllables" (Crossing the Water, 1971: 1, versos 33-34). Lo mismo ocurre también en poemas como "Two Campers in Cloud Country", donde los protagonistas "mean so little" (Crossing the Water, 1971: 32-32, verso 17). Como sugiere Joyce Carol Oates, "There is never any integrating of the self and its experience, the self and its field of perception. Human consciousness, to Sylvia Plath, is always an intruder in the natural universe" (1974: 149). Por ello la naturaleza tiene sus propias reglas y actúa sin tener en cuenta la presencia del hombre. De ahí que, refiriéndose a las nubes, Plath afirme: "No gesture of yours or mine could catch their attention, / No word make them carry water or fire the kindling / Like local trolls in the spell of a superior being" (Crossing the Water, 1971: 32-32, versos 4-6). También las rocas "are conceiving a dynasty of perfect cold" (verso 19) y el resultado final ante tan fría indiferencia es una necesidad de autodefinición del ser humano: "... Tell me I'm here" (verso 21). En otro poema de Crossing the Water, "Finisterre", queda, además, patente el hecho de que la ayuda divina no tiene poder de intervención ante las fuerzas naturales. Así, el marinero en forma de estatua de mármol que aparece rezando a la gigantesca imagen de la Virgen (Nuestra Señora de los Naufragios) y la mujer enlutada que reza delante de ambos, serán desoídos y sus súplicas no tendrán ningún efecto: "She [the Lady of the Shipwrecked] does not hear what the sailor or the peasant is saying - / She is in love with the beautiful formlesness of the sea" (1971: 3, versos 26-27). Hay una amarga ironía en el hecho de que la Virgen de los Naufragios se ponga de parte del elemento marino, informe, incontrolable, peligroso, olvidando así las plegarias de los más débiles.

\section{VULNERABILIDAD}

El ser humano percibe la hostilidad del medio natural desde una posición de evidente vulnerabilidad. Por esto, en poemas anteriormente citados como "Hardcastle Crags" y "Wuthering Heights" a la sensación de hostilidad del medio hay que sumar el sentimiento de vulnerabilidad y de impotencia para actuar sobre él. La sensación de impotencia y negatividad es progresiva en la obra de la escritora y así, en sus últimos poemas se hace más y más evidente. En "Totem" la sensación de fatalidad, de implacabilidad del destino, es patente ya en los primeros versos: 
The engine is killing the track, the track is silver,

It stretches into the distance. It will be eaten nevetheless.

Its running is useless.

At nightfall there is the beauty of drowned fields. (Ariel, 1965: 75, versos 1-3)

Como hemos comentado con anterioridad, ésta es una característica que la distingue de Hughes, en cuyos versos se atisba la esperanza de una posible reconciliación entre el ser humano y su medio circundante.

Respecto al sentimiento de vacío que el paisaje puede generar, podemos hacer referencia a algún que otro poema como "Winter Trees", en el que la fertilidad del medio que rodea a la protagonista no hace sino agudizar su tristeza ante su incapacidad de generar vida. Rosenblatt afirma al respecto:

Absence is again made the dominant theme of the landscape. The three stanzas develop three related aspects of fertility: the symbolic "wedding" of the past and future of trees through the formation of rings; the effortless germination of seeds; and the motherly and divine quality of the Ledalike trees. In comparison with the organic rootedness and innocence of the trees, women seem devoted to sterility ("abortions") and cruelty ("bitchery"). The poem contrasts the pure, organic spontaneity of the natural world with the tortured, inauthentic life of women ... (1979: 103-04)

Por tanto, de nuevo aquí la naturaleza es presentada como fuente de sufrimiento para la escritora, quien en estos momentos anhela ser madre y ve la exuberancia de la vida alrededor como algo que le infringe dolor ya que acentúa su propia carencia.

\section{IDENTIFICACIÓN Y FUSIÓN}

Como Picot explica en su libro, Outcasts from Eden, la caída en desgracia del hombre tras sublevarse contra la autoridad divina y su salida del jardín del Edén donde vivía en armonía con la naturaleza, han llevado al mismo a tener que utilizar su propia inteligencia para moverse por el mundo ya que ahora carece de la guía y el apoyo divino que antes poseía:

Since the Fall, he has been obliged to rely on his own flawed intelligence, instead of on God's guidance and support, and he has always been at odds with the natural world. The results are the ugly, manmade muddles that we see all around us today. The Eden-myth thus encourages us to believe that the natural world is closer to God than we are; and that, as a consequence, it possesses a moral purity and aesthetic beauty which we have lost. (1997: 15)

Así, el ser humano sigue mirando hacia la naturaleza esperando encontrar en ella la primigenia pureza moral y belleza estética que necesita en su vida. Plath busca en el mundo natural la armonía y paz interior que le faltan pero pronto se da cuenta de que no sólo encuentra indiferencia sino también una hostilidad ante la que se siente vulnerable, pues la naturaleza es suceptible de maldad. Como señala Melander, 
The expression "bad nature" is worth special attention, because here Sylvia Plath's notion of nature's inherent hostility to its kind is formulated so as to indicate that nature, personified, is charged with a force which, by implication, both maintains and extinguishes life. It is of vital importance to stress that to Sylvia Plath nature appears basically evil and destructive, not basically benevolent. (1972: 55)

Encontramos, por tanto, una contradicción inherente en Plath como inherente es, en sí misma, la contradicción en todo ser humano: por un lado, persigue e insiste en la identificación y reunión con lo que se supone es la fuente de bondad natural, por otro, resulta decepcionada, derrotada, herida, pues se da cuenta una y otra vez, que tal comunión es imposible.

Poemas en los que Plath trata sobre identificación y fusión en cuanto a la relación existente entre ser y paisaje son, predominantemente, poemas transicionales como los que componen el grupo "Poem for a Birthday", compuesto por "Who", "Dark House", "Maenad", "The Beast" y "Witch Burning", poemas recogidos en Crossing the Water, y "Flute Notes from a Reedy Pond" y "The Stones", publicados en The Colossus. En todos ellos el tema común es la regresión del ser a un estado más primitivo y, para ello, los cambios físicos son necesarios. De esta manera, y tal como describe Rosenblatt,

Instead of looking at the dead, though, either as animals, natural forms, corpses, family members, or women, Plath now becomes the objects she has feared: she turns into a mole ("Who"); becomes a stone ("The Stones"); dies as a witch on the stake ("Witch Burning"); goes underground into the landscape ("The Beast"). (1979: 83)

No obstante, ya en un poema temprano escrito en 1958 y recogido en The Colossus, "Mussel Hunter at Rock Harbor", aparece la idea de que, en realidad, tal fusión con la naturaleza es imposible pues el mundo exterior, por algún misterio extraño que Plath no es capaz de descifrar, la ha rechazado:

.... They moved

Obliquely with a dry-wet

Sound, with a glittery wisp

And trickle. Could they feel mud

Pleasurable under claws

As I could between bare toes?

That question ended it-I

Stood shut out, for once, for all, Puzzling the passage of their

Absolutely alien

Order...

(The Colossus and Other Poems, 1962: 71, versos 45-55) (Énfasis mío)

Hay muchos otros poemas en los que vemos un intento de identificación del ser con el medio pese a la imposibilidad inherente de la empresa. En "Parliament Hill Field", la 
protagonista, que parece haber sufrido un aborto, encuentra consuelo en el paisaje que le rodea, ya que éste se parece mucho a su propio paisaje interior caracterizado por el sentimiento de pérdida y aislamiento, y a la separación del resto del mundo. El paisaje aquí, como en muchos otros poemas transicionales, se ha convertido en un espejo donde el ser humano puede verse reflejado. También cabe mencionar, a propósito de la imagen del espejo, versos como los de "Poppies in July", "Poppies in October" y "Among the Narcissi". En el primero de estos poemas, a Plath le gustaría convertirse en lo que ve reflejado en ese espejo y exclama: "If I could bleed, or sleep! - / If my mouth could marry a hurt like that!" (The Collected Poems, 1981: 203, versos 11-12). En "Poppies in October" y "Among the Narcissi" no es ella la que se ve en el espejo circundante sino una mujer en una ambulancia, cuyo corazón se asemeja a las amapolas, y Percy, un vecino de Plath en Devon, cuyo dolor físico parecen sentir, a su vez, los blancos narcisos de marzo: “... they suffer such attacks!" (Winter Trees, 1972: 15, verso 9).

En cuanto a los poemas escritos al final de su vida, es obvio que el tema de la identificación entre protagonista y paisaje está también presente. En poemas como "Elm", el protagonista es un árbol. También en "Edge" la mujer que protagoniza los versos se convierte, metafóricamente, en una rosa y sus hijos en sus pétalos, siendo ambos absorbidos por la dulzura del jardín, que representa, a su vez, su morada final tras la transformación.

Intentando dar una explicación a esta necesidad de Plath de fundirse por completo con el medio circundante, hay autores como Rosenblatt que explican que su actitud representa, en definitiva, una huída de su propio cuerpo que es su principal fuente de dolor. De ahí el deseo último de la escritora de abandonar su cuerpo y fundirse con la realidad que le rodea (1971: 150-51). El problema con el que se encuentra Plath es que el rechazo de su propio cuerpo, que le hace vulnerable y es la fuente última de su dolor, lleva implícito en sí el fracaso de su deseo de lograr una fusión exitosa, una unión armoniosa con el medio circundante. Al rechazarse a sí misma, su método de fusión con la realidad circundante se convierte, por tanto, en una trampa y hace inevitable el fracaso final.Teorías más recientes, como la mencionada anteriormente, atribuirían el deseo de identificación de Plath a la búsqueda de una realidad ajena al dolor. En efecto, Plath se sentía inmersa en un medio que le era hostil y en el que siempre luchó por integrarse. Sus esfuerzos desesperados por rehacer su vida tras su separación de Ted Hughes, su marido, y acomodarse a una nueva situación, se asemejan a los esfuerzos de sus protagonistas por integrarse en el medio natural descrito en sus poemas, buscando en él la pureza y bondad primigenias del ser humano. No obstante, tales esfuerzos no se ven nunca recompensados y el desánimo final y el sentimiento de derrota resultan patentes tanto en sus últimos versos escritos como en su propia vida.

\section{BIBLIOGRAFÍA}

Adorno, T. W. y M. Horkheimer. 2000. "The logic of domination". The Green Studies Reader. From Romanticism to Ecocriticism. Ed. L. Coupe. London \& New York: Routledge. 77-80.

Applewhite, J. 1985. Seas and Inland Journeys. Landscapes and Consciousness from Wordsworth to Rohtke. Athens: University of Georgia Press.

Arnold, M. 1979. The Poems of Matthew Arnold. Ed. K. Allot y M. Allott. London: Longman Group Limited.

Odisea, $n^{\circ} 2,2002$ 
Axelrod, S. G. 1985. "The second destruction of Sylvia Plath". American Poetry Review. Marzo-Abril: 17-18. Reimprimido en Sylvia Plath: The Critical Heritage. 1988. Ed. L. W. Martin. London \& New York: Routledge. 313-19. . 1990. Sylvia Plath. The Wound and the Cure of Words. Baltimore: The Johns Hopkins University Press.

Coupe, L. ed. 2000. The Green Studies Reader. From Romanticism to Ecocriticism. London \& New York: Routledge.

Dyson, A. E. 1970. “On Sylvia Plath”. The Art of Sylvia Plath. A Symposium. Ed. Charles Newman. Bloomington: Indiana University Press. 204-10.

Eliot, T.S. 1950. "Tradition and the individual talent". Selected Essays. New York: Harcourt. 13-22. 1987 (1969). The Complete Poems and Plays. London: Faber and Faber.

Fitter, C. 1995. Poetry, Space, Landscape. Toward a New Theory. Cambridge: Cambridge University Press.

Freud, S. 1990. "The uncanny". The Penguin Freud Library. London: Penguin Books. Vol. 14: 335-76.

Gifford, T. 2000. "Pastoral, anti-pastoral, post-pastoral". The Green Studies Reader. From Romanticism to Ecocriticism. Ed. L. Coupe. London \& New York: Routledge. 219-222.

Hargrove, N. D. 1978. Landscape as Symbol in the Poetry of T.S. Eliot. Jackson: University Press of Mississippi.

Hughes, T. 1977. "Introduction". Johnny Panic and the Bible of Dreams and Other Prose Writings by Sylvia Plath. London: Faber and Faber Limited. 11-20.

. 1987 (1982). "Foreword". The Journals of Sylvia Plath. Ed. T. Hughes \& F. McCullough. New York: Ballantine Books. xiii-xv.

\section{3.}

. 1994. "Myth and education". Winter Pollen. London: Faber \& Faber. 136-

Kazin, A. 1988. A Writer's America. Landscape in Literature. New York: Alfred A. Knopf.

Koolhas, R. 1994. Delirious New York. A Retroactive Manifesto for Manhattan. Rotterdam: 010 Publishers.

Lorsch, S. E. 1983. Where Nature Ends. London and Toronto: Associated University Presses, Inc.

Lucie-Smith, E. 1970. "Sea-imagery in the work of Sylvia Plath". The Art of Sylvia Plath. Ed. C. Newman. Bloomington \& London: Indiana University Press. 91-99.

Machor, J. L. 1987. Pastoral Cities. Urban Ideals and the Symbolic Landscape of America. Wisconsin: The University of Wisconsin Press.

Macpherson, P. 1991. Reflecting on «The Bell Jar». New York: Routledge.

Malcolm, J. 1993. «The silent woman”. The New Yorker 23 \& 30 Agosto: 84-159. . 1994. The Silent Woman: Sylvia Plath \& Ted Hughes. New York: Alfred A. Knopf. 
Mckibben, B. 1990. The End of Nature. London: Penguin.

Melander, I. 1972. The Poetry of Sylvia Plath: A Study of Themes. Stockholm: Almqvist \& Wiksell.

Mulvey, C. 1983. Anglo-American Landscapes. A Study of Nineteenth-Century Anglo-American Travel Literature. Cambridge: Cambridge University Press.

Newman, C., ed. 1970. The Art of Sylvia Plath. A Symposium. Bloomington: Indiana University Press.

Oates, J. C. 1974. "The death throes of Romanticism. The poems of Sylvia Plath". Contemporary Poetry in America. Essays and Interviews. Ed. R. Boyers. New York: Schocken Books. 145-150.

Pâtea, V. 1989. Entre el Mito y la Realidad: Aproximación a la Obra Poética de Sylvia Plath. Salamanca: Ediciones Universidad de Salamanca.

Perloff, M. 1984. "Angst and animism in the poetry of Sylvia Plath". Critical Essays on Sylvia Plath. Ed. L. W. Wagner-Martin. Boston: G. K. Hall \& Company. 53-55.

Picot, E. 1997. Outcasts from Eden. Ideas of Landscape in British Poetry since 1945. Liverpool: Liverpool University Press.

Plath, S. 1962 (1957). The Colossus and Other Poems. New York: Alfred A. Knopf. . 1965. Ariel. New York: Harper and Row, Publishers.

. 1970. "Ocean 1212-W". The Art of Sylvia Plath: A Symposium. Ed. C.

Newman. Bloomington \& London: Indiana University Press. 266-72.

. 1971. Crossing the Water. New York: Harper \& Row, Publishers.

1972. Winter Trees. New York: Harper \& Row, Publishers.

. 1977. Johnny Panic and the Bible of Dreams. London: Faber \& Faber Ltd.

. 1981. The Collected Poems. New York: Harper \& Row, Publishers.

. 1987. The Journals of Sylvia Plath. New York: The Dial Press.

. 1988. The Bell Jar. New York: Bantam Books.

. 1992. Letters Home. New York: Harper \& Row, Publishers.

.2000. The Journals of Sylvia Plath (1950-62). Ed. K. V. Kukil. London: Faber \& Faber.

Porteous, J. D. 1990. Landscapes of the Mind. Worlds of Sense and Metaphors. Toronto: University of Toronto Press.

Rose, J. 1991. The Haunting of Sylvia Plath. London: Virago.

Rosenblatt, J. 1979. "Sylvia Plath: The drama of initiation". Twentieth Century Literature 25.1: 21-36.

Roszak, T. 2000. "Against single vision". The Green Studies Reader. From Romanticism to Ecocriticism. Ed. L. Coupe. London \& New York: Routledge. 109114.

Scheerer, C. 1977. "The deathly paradise of Sylvia Plath". Sylvia Plath: The Woman and the Work. Ed. E. Butscher. New York: Dodd, Mead \& Company. 166-76. 
Scheese, D. 1996. Nature Writing. The Pastoral Impulse in America. New York: Twayne Publishers.

Simpson, L. 1978. A Revolution in Taste. New York: Macmillan Publishers.

Stevenson, A. 1989. Bitter Fame. Boston: Houghton Mifflin Company.

Tuan, Y. F. 1979. Landscapes of Fear. New York: Pantheon.

Vidler, A. 1992. The Architectural Uncanny. Essays in the Modern Unhomely. Cambridge, Massachusetts: MIT Press.

Wagner-Martin, L. W. 1988. "The journals of Sylvia Plath". Sylvia Plath: The Critical Heritage. Ed. L. W. Wagner-Martin. London \& New York: Routledge. 306-8.

\section{Company.}

ed. 1984. Critical Essays on Sylvia Plath. Boston: G.K. Hall \& . 1987. Sylvia Plath: A Biography. New York: St. Martin's Press. . ed. 1988. Sylvia Plath. New York: Routledge. 